\title{
Emotional and Behavioral Consequences of Cross-Border Shopping
}

\author{
Liane Nagengast, Marc Linzmajer, Tim Boettger, and Thomas Rudolph
}

Motivated by potential savings, an increasing number of consumers travel to neighboring countries for the main purpose of shopping (e.g., Canadians to the USA, Swiss to Germany). This cross-border shopping might seriously harm local economies, for example in terms of revenue, unemployment, and social well-being.

In a quasi-field experiment with 301 Swiss consumers, we show that crossborder shoppers are consciously aware that their behavior might harm their local economy. They feel inner conflicts which affect their shopping emotions and their intended future cross-border purchases. Moreover, referring to Attribution Theory, we show that consumers' inner conflicts depend on who they blame for the price differences between the countries. Consumers who attribute price differences to internal causes (i.e., national retailers) feel less conflicted than consumers who attribute the price differences to external causes (i.e., the foreign economy).

These results have important implications for local retailers and public policy makers. Cross-border shopping behavior can be influenced by actively communicating the reasons for price differences between neighboring countries.

L. Nagengast $(\bowtie) \bullet$ M. Linzmajer $\bullet$ T. Boettger $\bullet$ T. Rudolph

University of St. Gallen, St. Gallen, Switzerland

e-mail: liane.nagengast@unisg.ch; marc.linzmajer@unisg.ch; tim.boettger@unisg.ch;

thomas.rudolph@unisg.ch 